\title{
ANALISIS RASIO DAN ECONOMIC VALUE ADDED (EVA) UNTUK MENILAI KINERJA KEUANGAN PT. HM. SAMPOERNATbk. TAHUN 2014 - 2016
}

\author{
Wakhid Yuliyanto dan Firgian Rafingki \\ Politeknik Dharma Patria Kebumen \\ wyuliyanto45@gmail.com \\ firgian_16311001_dharma@yahoo.com
}

\begin{abstract}
Abstrak
Penelitian ini bertujuan untuk mengetahui kinerja keuangan berdasarkan hasil perhitungan Analisis Rasio dan Economic Value Added (EVA) pada laporan keuangan PT. HM. Sampoerna Tbk pada tahun 2014 - 2016 dikarenakan dalam setiap laporan tahunan belum dijelaskan bagaimana kondisi kinerja keuangan perusahaan tersebut. Penelitian ini merupakan penilitian deskriptif kuantitatif. Metode analisis data yang digunakan adalah Analisis Rasio dan Economic Value Added (EVA). Analisis rasio yang digunakan adalah Rasio Liquiditas (Current Ratio, Quick Ratio,Cash Ratio), Rasio Solvabilitas (Debt to Assests Ratio, Debt to Equity Ratio), Rasio Aktivitas (Inventory Turn Over Ratio, Total Assets Turn Over) Dan Rasio Profitabilitas (Return On Assest, Return On Equity). Dari hasil perhitungan Analisis rasio perusahaan dalam kondisi kinerja keuangan yang baik jika dinilai dari Rasio Likuiditas, Rasio Solvabilitas, Rasio Akivitas dan Rasio Profitabilitas dikarenakan hasilnya berada di atas rata - rata industri yang sejenis. Sementara itu untuk hasil perhitungan menggunakan metode EVA dalam kurun waktu 2014 - 2016 hasilnya semuanya bernilai positif yang maknanya ada penambahan nilai yang menunjukan kinerja keuangan PT HM Sampoerna Tbk dalam kondisi yang baik. Berdasarkan hasil analisis bahwa secara keseluruhan kinerja keuangan PT. HM. Sampoerna Tbk. pada tahun 2014 - 2016 baik dengan adanya kenaikan laba setiap tahunnya. Namun perusahaan belum memaksimalkan sumber dana untuk menghasilkan laba.
\end{abstract}

Kata kunci : Kinerja keuangan, Rasio keuangan, Economic Value Added.

\section{Abstract}

This purpose of this research is to identify the financial performance based on the result of calculation Analisys Ratio and Economic Value Added ( EVA ) in the financial report of PT. HM. Sampoerna Tbk period 2014 - 2016 because of in every annual report there was un explaining how condition of financial performance of this company. This research it is a quantitative descriptive research. The method used was Analysis Ratio and Economic Value Added (EVA). Analysis Ratio used was Liquidity Ratio (Current Ratio, Quick Ratio,Cash Ratio), Solvability Ratio (Debt to Assests Ratio, Debt to Equity Ratio), Activity Ratio (Inventory Turn Over Ratio, Total Assets Turn Over) and Profitability Ratio (Return On Assest, Return On Equity). For the result of the calculation Analysis Ratio the company in condition good condition of the financial performance if assess from Liquidity Ratio, Solvability Ratio, Activity Ratio and Profitability Ratio because of the result was over average of a kind industry. Meanwhile the result which is used was EVA in period 2014 - 2016 the result all of them positive value which mean there is value added which is indication PT. HM. Sampoerna Tbk in good condition of the financial performance. Based on result of the analysis overall financial performance of PT. HM. Sampoerna Tbk. in 2014 - 2016 is good with revenue increase every year. However the company has not maximized fund resources to making a profit.

Keywords : Financial Perfomance, financial ratio, Economic Value Added.

\section{A. PENDAHULUAN}

1. Latar Belakang Permasalahan

Salah satu produsen terkemuka di Indonesia adalah PT. HM. Sampoerna Tbk. PT. HM. Sampoerna Tbk. merupakan produsen yang memproduksi sejumlah merek rokok kretek yang telah dikenal luas oleh masyarakat. Pada tahun 2016 PT. HM. Sampoerna Tbk. berhasil sebagai pemimpin pasar dengan pangsa pasar sebesar 33,4\% dari pasar rokok di Indonesia. PT. HM. Sampoerna Tbk. mempunyai banyak anak perusahaan yang tersebar diseluruh Indonesia dan juga berkerja sama dengan 38 Mitra Produksi Sigaret yang telah menyerap puluhan ribu pegawai kerja. 
Pada tahun 1990, PT. HM. Sampoerna Tbk. melakukan penawaran umum ( Public Offering ) kepada masyarakat luas sehingga menjadi perusahaan yang Go Public. Seperti halnya perusahaan Go Public pada umumnya, PT. HM. Sampoerna Tbk. mempublikasikan laporan keuangan tahunan pada website resminya. Laporan keuangan sendiri merupakan akhir dari siklus akutansi. Menurut Harahap (2007:105)“laporan keuangan menggambarkan kondisi keuangan perusahaan dan hasil usaha suatu perusahaan pada saat tertentu atau jangka waktu tertentu".

Namun dalam laporan keuangan tersebut belum dijelaskan bagaiman kinerja keuangan pada perusahaan tersebut. Pengujian kinerja keuanganpadapenelitianini menggunakan metode Analisis Rasio dan Economic Value Added (EVA). Analisis rasio merupakan alat untuk menjelaskan hubungan antara satu factor dengan yang lain dalam laporan keuangan, tetapi analisis rasio keuangan ini memiliki kelemahan.

Kelemahannya yaitu dengan mengabaikan biaya modal pada perusahaan tersebut. Karena mengabaikan biaya modal, sulit untuk diketahui apakah perusahaan tersebut telah menghasilkan nilai tambah atau tidak.Mengatasi kelemahan tersebut, selain menggunakan metode analisis rasio keuangan, suatu perusahaan biasanya akan menggunakan metode lain. Salah satu metode yang digunakan adalah metode Economic Value Added (EVA). Oleh karena itu penulis membuat penelitian tentang " ANALISIS RASIO DAN ECONOMIC VALUE ADDED (EVA) UNTUK MENGUKURKINERJA KEUANGAN PADA PT. HM. SAMPOERNA Tbk. PADA TAHUN $2014-2016$ “.

Adapun penelitian sebelumnya yang membahas tentang hal yang serupa yaitu " PERBANDINGAN ANTARA ECONOMIC VALUE ADDED (EVA) DAN RETURN ON ASSETS (ROA) DALAM MENILAI KINERJA PERUSAHAAN (Studi kasus pada perusahaan rokok go publik yang terdaftar di Bursa EfekIndonesia periode 2010-2012) “ yang ditulis oleh Ria Ayu Dewi pada tahun 2014. Dalam penelitian tersebut penulis membandingkan penilaian kinerja perusahaan rokok go public dengan menggunakan metode Economic Value Added (EVA) dengan Return On Assets (ROA) yang dimana salah satu perusahaan yang dinilai kinerjanya yaitu PT. HM. Sampoerna Tbk.

Mengacu pada penelitian tersebut penulis tertarik untuk melanjutkan penelitian tersebut dengan menambahkan beberapa variable yang berupa Analisis Rasio. Dalam penelitian sebelumnya metode EVA (Economic Value Added) dinilai lebih menguntungkan dibanding dengan metode Return On Assets (ROA) dikarenakan dengan menggunakan EVA membantu para manajer untuk membuat keputusan investasi yang lebih baik, mengidentifikasikesempatan-kesempatan untuk meningkatkan kinerja dan mempertimbangkanbenefit jangka panjang dan jangka pendek untuk perusahaan. Sedangkan metode Return On Assets (ROA) dinilai kurang menguntungkan karena dalam perhitungannya tidak memperhatikan besarannya sumber dana.

\section{B. METODE PENELITIAN}

\section{Metode Penelitian}

Dalam melakukan penelitian dan pembuatan Tugas Akhir penulis menggunakan dua jenis Metode Penelitian yaitu dengan Analisis rasio dan Economic Value Added (EVA) yang dimana akan menghasilkan suatu nilai yang akan digunakan untuk mengukur kinerja PT. HM. Sampoerna Tbk. dalam kurun waktu 2014 - 2016. Penelitian ini merupakan penelitian deskriptif dengan pendekatan secara kuantitatif. Yang artinya penelitian yang menghasilkan angka - angka kemudian dijelaskan secara deskriptif.

Objek dalam penelitian ini adalah Laporan keuangan PT. HM. Sampoerna Tbk. Tahun 2014 2016 yang sudah diaudit oleh Auditor. Penelitian ini bersumber pada sumber data sekunder. data sekunder adalah penelitian yang diperoleh secara tidak langsung, bisa melalui internet, jurnal, buku ilmiah ataupun referensi lainnya.

\section{Definisi Operasional Variabel}

Operasional variabel dalam penelitian ini sebagai berikut:

a. Variabel RasioLikuiditas adalah Rasio yang digunakan untuk mengukur kemampuan perusahaan dalam membiayai kewajiban jangka pendek ketika sudah jatuh tempo dengan melihat aktiva lancar perusahaan terhadap hutang lancar.. Indikatornya adalah Currenr ratio, Quick ratio, dan Cash ratio. 
b. Variabel Rasio Solvabilias adalah Rasio yang menunjukan bagaimana perusahaan menggunakan utang - utang jangka panjangnya untuk dijadikan sebagai pembiayaan aktiva perusahaan itu sendiri. IndikatornyaadalahDebt to Asset Ratio dan Debt to Equity Ratio.

c. Variabel RasioAktivitas adalah Rasio yang menggambarkan bagaimana perusahaan tersebut menggunakan aktiva tetapnya yang digunakan untuk menjalankan operasional perusahaan secara efektif dan efisien. Indikatornya adalah Inventory turnover ratiodanTotal asset turnover ratio.

d. Variabel RasioProfitabilitas adalah Rasio yang mengukur kemampuan perusahaan dalam menghasilkan laba selama periode tertentu dan juga memberikan gambaran tentang tingkat efektifitas manajemen dalam melaksanakan kegiatan operasinya (Abdul,2010:25). Indikatornya Return on asset ratiodan Return on equity ratio.

e. Economic Value Added (EVA) adalah metode penilaian nilai tambah perusahaan dengan menghitung Laba Bersih Operasional Setelah Pajak (Net Operating Profit After Tax) dengan biaya Modal yang dimana dalam biaya modal itu sendiri ditentukan oleh biaya rata-rata tertimbang dari Hutang dan Ekuitas.

\section{Teknik Pengumpulan Data}

Teknik pengumpulan data yang digunakan dalam penelitian ini adalah kepustakaan. Teknik kepustakaan merupakan teknik pengumpulan data dengan cara mempelajari dan menelaah berbagai sumber kepustakaan yang relevan yang bersangkutan dengan masalah yang penelitian yang dilakukan. Kegiatan tersebut dalam rangka memperoleh kejelasan konsep dan landasan teori yang akan digunakan untuk memberi tinjauan atas permasalahan yang dibahas.

\section{Teknik Analisis Data}

Teknik analisis data yang digunakan sebagai berikut:

a. Analisis Rasio Likuiditas

1) Current ratio merupakan menunjukkan hubungan antara aktiva lancar dengan kewajiban lancar suatu perusahaan. Current ratioyang tinggi memberikan indikasi jaminan yang baik bagi kreditur artinya setiap saat perusahaan memiliki kemampuan untuk melunasi kewajiban jangka pendeknya.Currentratio dapat dihitung dengan rumus :

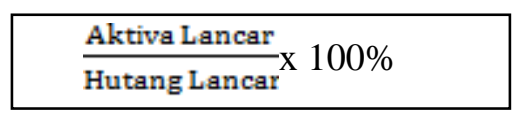

2) Quick ratio merupakan merupakan rasio uji cepat yang menunjukkan kemampuan perusahaan membayar kewajiban jangka pendek dengan aktiva lancar tanpa memperhitungkan persediaanQuick ratio dapat dihitung dengan rumus:

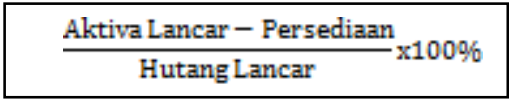

3) Cash ratiomerupakan rasio untuk mengukur seberapa besar uang kas yang tersedia untuk membayarkan hutanglancar / kewajiban jangka pendeknya.Rasio ini dapat dihitung dengan rumus

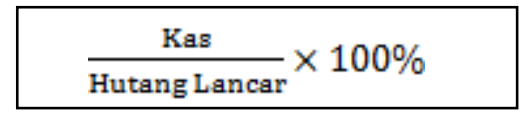

b. Rasio Solvabilitas

1) Debt to Assets Ratiomerupakan rasio perbadingan antara total hutang dengan total aktiva. Dengan kata lain, seberapa besar aktiva perusahaan dibiayai oleh hutang atau seberapa besar utang perusahaan berpengaruh terhadap pengelolaan aktiva (Kasmir, 2008:156) . Rumusnyasebagaiberikut :

$$
\frac{\text { Total Hutang }}{\text { Total Aktiva }} \times 100 \%
$$


2) Debt to Equity Ratiomerupakan rasio yang digunakan untuk menilai hutang dengan ekuitas. Rasio ini berguna untuk mengetahui jumlah dana yang disediakan peminjam (kreditor) dengan pemilik perusahaan (Kasmir,2008:157-158).Rumusnya sebagai berikut :

\section{$\frac{\text { Total Hutang }}{\text { Modal Sendiri }} \times 100 \%$}

c. Rasio Aktivitas

1) Inventory turnover ratio merupakan rasio yang mengukur seberapa efektif perputaran persediaan.Semakin tinggi inventory turn over, maka semakain baik dan efisien modal kerja yang ditanamkan dalam persediaan(Aditya, 2015:10).Rasio ini dapat hitung dengan rumus :

\section{Harga Pokok Penjualan}

Rata-rataPersediaan

2) Total asset turnover ratio merupakan rasio yang mengukur seberapa efektif perputaran aktiva dengan cara membandingkan antara penjualan bersih dengan total aktiva. Rasio ini dapat hitung denganrumus:

$\frac{\text { Penjualan Bersih }}{\text { Total Aktiva }}$

d. Rasio Profitabilitas

1) Return on asset merupakan rasio yang digunakan untuk mengukur kemampuan dari modal yang diinvestasikan dalam keseluruhan aktiva untuk menghasilkan keuntungan bersih. Rasio ini dapat dihitung dengan rumus:

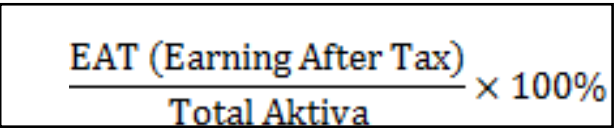

2) Return on equity ratio merupakan rasio yang digunakan untuk mengukur kemampuan dari modal sendiri untuk untuk menghasilkan keuntungan bagi seluruh pemegang saham, rasio ini menunjukan efisiensi penggunaan modal sendiri.Rasio ini dapat dihitung dengan rumus:

\section{EAT ( Eam After Tax \\ Modal Sendiri $\times 100 \%$}

e. Economic Value Added (EVA)

Merupakan metode penilaian nilai tambah perusahaan dengan menghitung Laba Bersih Operasional Setelah Pajak (Net Operating Profit After Tax) dengan biaya Modal yang dimana dalam biaya modal itu sendiri ditentukan oleh biaya rata-rata tertimbang dari Hutang dan Ekuitas. Rumusnya

$$
\text { EVA }=\text { NOPAT }- \text { Capital Charges }
$$

Sumber :Supriyanto dan Widianti (2015:55)

*Capital Charges

Invested Capital x WACC 
*Net Operating Profit After Tax

(NOPAT)

EBIT - Pajak

*Invested Capital

Total Hutang \& Equitas - Hutang Jk. Pendek

* Weighted Average Cost of Capital (WACC)

$$
[(\mathrm{D} x \mathrm{rd})(1-\mathrm{Tax})+(E \mathrm{xre})]
$$

*Cost of Debt (rd)

*Tingkat Modal dari Hutang (D)

$$
\frac{\text { Beban Bunga }}{\text { Total Utang }} x 100 \%
$$

$$
\frac{\text { Total Utang }}{\text { Total Utang dan Equitas }} x 100 \%
$$

*Cost of Equity (re)

$$
\frac{\text { EAT }}{\text { Total Equitas }} x 100 \%
$$

*Tingkat Equitas (E)

$$
\frac{\text { Total Equitas }}{\text { Total Utang dan Equitas }} x 100 \%
$$

*Tingkat Pajak (Tax)

$$
\frac{\text { Beban Pajak }}{\text { EBIT }} x 100 \%
$$

C. PEMBAHASAN DAN HASIL

1. Hasil PerhitungandanPembahasan Rasio Likuiditas 2014- 2016.

a. Current ratio

Tabel 3.1 HasilCurrent Ratio

\begin{tabular}{|c|c|c|}
\hline Tahun & Current Ratio & *Rata - rata \\
\hline 2014 & $152,77 \%$ & $161,15 \%$ \\
\hline 2015 & $656,74 \%$ & $353,87 \%$ \\
\hline 2016 & $523,41 \%$ & $324,20 \%$ \\
\hline
\end{tabular}

Sumber : Data di olah. 
*Rata - rata Industri sejenis.

Hasil perhitungan Current ratio pada tahun 2014-2016 menunjukkan bahwa Current rasio pada tahunmengalamikenaikan2015 sebesar 503,97\%yaitudari yang sebelumnya 152,77\% menjadi $656,74 \%$.Lalu pada tahun 2016 current ratiomengalami penurunan sebesar 133,33\%dari yang sebelumnya $656,74 \%$ menjadi $523,41 \%$.

Untuk rata - rata current ratio dalam kurun waktu 2014-2016 PT. HM. Sampoerna Tbk sebesar 4,44artinya setiap Rp 1 hutang lancar dapat dijamin oleh aktiva lancar sebesar Rp 4,44.

b. Quick ratio

Tabel 3.2 HasilQuick Ratio

\begin{tabular}{|c|c|c|}
\hline Tahun & Quick Ratio & *Rata - rata \\
\hline 2014 & $24,60 \%$ & $29,83 \%$ \\
\hline 2015 & $236,54 \%$ & $90,07 \%$ \\
\hline 2016 & $220,98 \%$ & $93,41 \%$ \\
\hline
\end{tabular}

Sumber : Data di olah.

*Rata - rata Industrisejenis.

Hasil perhitungan Quick ratioPT. HM. Sampoerna Tbk. berfluktuatif. Pada tahun 2015 mengalami kenaikan sebesar 211,94\%dari yang sebelumnya 24,60\% menjadi 236,54\%, lalu pada tahun 2016 Quick ratiomengalami sedikit penurunan yaitu sebesar 15,56\%dari yang sebelumnya 236,54\% menjadi $220,98 \%$.

Untuk rata - rata Quick ratio dalam kurun waktu 2014-2016 PT. HM. Sampoerna Tbk adalah sebesar 1,60artinya setiap Rp 1 hutang lancar dapat dijamin oleh aktiva lancar sebesar Rp 1,60.

c. Cash ratio

Tabel 3.3HasilCash Ratio

\begin{tabular}{|c|c|c|}
\hline Tahun & Cash Ratio & *Rata - rata \\
\hline 2014 & $0,48 \%$ & $6 \%$ \\
\hline 2015 & $37,87 \%$ & $20,44 \%$ \\
\hline 2016 & $78,65 \%$ & $28,87 \%$ \\
\hline
\end{tabular}

Sumber : Data di olah.

* Rata - rata Industri sejenis.

Dari perhitungan tabel diatas menunjukkan Cash ratio PT. HM. Sampoerna Tbk. kenaikan setiap tahunnya. Dimulai pada tahun 2015 mengalami kenaikan sebesar 37,29 \%.Kemudian pada tahun 2016 Cash ratiomengalami kenaikan yang besar yaitu sebesar 40,78\%.

Untuk rata - rata Cash ratio dalam kurun waktu 2014-2016 PT. HM. Sampoerna Tbk adalah sebesar $39 \%$ artinya setiap Rp 1 hutang lancar dapat dijamin oleh aktiva lancar sebesar Rp $39 \%$.

2. Hasil Perhitungan danPembahasanRasio Solvabilitas2014-2016.

a. Debt to Assets Ratio (DAR)

Tabel 3.4 Hasil DAR

\begin{tabular}{|c|c|c|}
\hline Tahun & DAR & $*$ Rata - rata \\
\hline 2014 & $52,44 \%$ & $<60,99 \%$ \\
\hline 2015 & $15,77 \%$ & $<52,62 \%$ \\
\hline
\end{tabular}




\begin{tabular}{|c|c|c|}
\hline 2016 & $19,60 \%$ & $<28,36 \%$ \\
\hline
\end{tabular}

\section{Sumber : Data di olah.}

*Rata - rata Industri sejenis.

Dari hasil perhitungan debt to asset ratio diatas pada tahun 2014 - 2016 mengalami kenaikan serta penurunan. Pada tahun 2015 mengalami penurunan sebesar 36,67\%.Kemudian pada tahun 2016 debt toasset ratio mengalami sedikit kenaikan yaitu sebesar $3,83 \%$.

Dengan demikian dapat diketahui bahwa kurun waktu 2014-2016 rata-rata debt to asset ratio PT. HM. Sampoerna Tbk. sebesar 29,27 \%. Artinya PT. HM. Sampoerna Tbk. memiliki risiko kegagalan yang kecil untuk mengembalikan hutang /pinjaman yang dimana akan dijamin dengan total aktiva sebesar $29,27 \%$.

b. Debt to Equity ratio (DER)

Tabel 3.5 Hasil DER

\begin{tabular}{|c|c|c|}
\hline Tahun & DER & $*$ Rata - rata \\
\hline 2014 & $110,26 \%$ & $>-176,26 \%$ \\
\hline 2015 & $18,72 \%$ & $>-93,55 \%$ \\
\hline 2016 & $24,38 \%$ & $<40,69 \%$ \\
\hline
\end{tabular}

Sumber : Data di olah.

*Rata - rata Indsutri sejenis.

Pada tahun 2015 terjadi penurunan yang sangat baik yaitu sebesar 91,53\%dari yang sebelumnya $110,26 \%$ menjadi $18,72 \%$. Kemudian pada tahun 2016 debt to equity ratio mengalami kenaikan yaitu sebesar 5,66\%ataumenjadi $24,38 \%$.

Dengan demikian dapat diketahui bahwa kurun waktu 2014-2016 rata-rata debt to equity ratio PT. HM. Sampoerna Tbk. sebesar 51,12\% artinya setiap Rp 1 total hutang dapat dijamin oleh modal sendiri sebesar Rp0,5112.

\section{Hasil Perhitungan dan Pemabahasan Rasio Aktivitas 2014-2016.}

a. Inventory Turn Over

Tabel 3.6 HasilInventory Turn Over

\begin{tabular}{|c|c|c|}
\hline Tahun & ITO & *Rata - rata \\
\hline 2014 & $41 \mathrm{kali}$ & $27 \mathrm{kali}$ \\
\hline 2015 & $42 \mathrm{kali}$ & $28 \mathrm{kali}$ \\
\hline 2016 & $44 \mathrm{kali}$ & $28 \mathrm{kali}$ \\
\hline
\end{tabular}

Sumber : Data di olah.

*Rata - rata Industrisejenis.

Dari hasil perhitungan inventory turn over diatas dari tahun 2014 - 2016 selalu mengalami kenaikan mulai dari 2014 ke 2015 menglami 1x kenaikan lalu 2015 ke 2016 mengalami 2x kenaikan.

Dengan demikian dapat diketahui bahwa kurun waktu 2014-2016 rata-rata inventory turn over PT. HM. Sampoerna Tbk. sebanyak 43x artinya perputaran persediaansebesar 43x menunjukkan bahwa dana yang tertanam dalam persediaan berputarsebanyak 43x dalam satu tahun .

b. Total Assets Turn Over (TATO)

Tabel 3.7 HasilTotal Assets Turn Over

\begin{tabular}{|c|c|c|}
\hline Tahun & TATO & *Rata - rata \\
\hline 2014 & $2,84 \mathrm{kali}$ & $1,64 \mathrm{kali}$ \\
\hline 2015 & $2,34 \mathrm{kali}$ & $1,54 \mathrm{kali}$ \\
\hline
\end{tabular}




\begin{tabular}{|c|c|c|}
\hline 2016 & $2,24 \mathrm{kali}$ & $1,53 \mathrm{kali}$ \\
\hline
\end{tabular}

Sumber : Data di olah.

* Rata - rata Industrisejenis.

Dari hasil perhitungan total assets turn over diatas terjadi penurunan ditiap tahunnya mulai dari tahun 2015 mengalami penurunan sebesar 0,5 kali , hal ini terlihat dari semula tahun 2014 sebesar 2,84 kali menjadi 2,34 kali. Kemudian pada tahun 2016 total assets turn over mengalami penurunan kembali sebesar 0,09 kali.

Dengan demikian dapat diketahui bahwa kurun waktu 2014-2016 rata-rata total assets turn over PT. HM. Sampoerna Tbk. sebanyak 2,4774x artinya perusahaan menghasilkan penjualan sebesar 2,4774x dengan memanfaatkan total aktiva yang dimiliki.

4. Hasil dan Pembahasan Rasio Profitabilitas tahun 2014 - 2016.

a. Return On Assets (ROA)

Tabel 3.8 HasilCurrent Ratio

\begin{tabular}{|l|l|l|}
\hline Tahun & ROA & *Rata - rata \\
\hline 2014 & $35,87 \%$ & $8,21 \%$ \\
\hline 2015 & $27,26 \%$ & $8,58 \%$ \\
\hline 2016 & $30,02 \%$ & $8,14 \%$ \\
\hline
\end{tabular}

Sumber : Data di olah.

*Rata - rata Industrisejenis.

Dari hasil perhitungan return on assets diatas pada tahun 2015 terjadi penurunan sebesar $8,61 \%$ darisebelumnya $35,87 \%$ menjadi $27,26 \%$. Selanjutnya pada tahun berikutnya pada tahun 2016 terjadi kenaikansebesar2,76\%daritahunsebelumnyayaitumenjadi 30,02\%.

Dengan demikian dapat diketahui bahwa kurun waktu 2014-2016 rata-rata return on assets PT. HM. Sampoerna Tbk. sebesar 31,05\% .Artinya bahwa penghasilan bersih yang di peroleh adalah sebesar $31,05 \%$ dari total aktiva yang digunakan.

b. Return on equity (ROE)

Tabel 3.9 HasilReturn On Equity

\begin{tabular}{|l|l|l|}
\hline Tahun & ROE & *Rata - rata \\
\hline 2014 & $75,43 \%$ & $70,22 \%$ \\
\hline 2015 & $32,37 \%$ & $28,75 \%$ \\
\hline 2016 & $37,34 \%$ & $10,56 \%$ \\
\hline
\end{tabular}

Sumber : Data di olah.

*Rata - rata Industrisejenis.

Dari hasil perhitungan Return On Equity diatas pada tahun 2015 mengalami penurunan sebesar 43,06 $\%$. Lalu pada tahun 2016 Return On Equity mengalami kenaikan sebesar 4,97. Dengan demikian dapat diketahui bahwa kurun waktu 2014 - 2016 rata-rata rasio Return On Equity PT. HM. Sampoerna Tbk. sebesar 48,38 artinya bahwa tingkat return (penghasilan) yang di peroleh pemilik perusahaan atas modal yang diinvestasikan adalah sebesar $48,38 \%$.

5. PenilaianKinerjaKeuanganPT. HM. SampoernaTbk. tahun $2014-2016$

\begin{tabular}{|l|c|c|c|c|c|}
\hline \multicolumn{7}{|c|}{ HASIL PERHITUNGAN ANALISIS 2014 } \\
\hline JENIS RASIO & 2014 & 2015 & 2016 & $\begin{array}{c}\text { Rata }- \\
\text { rata }\end{array}$ & Kondisi \\
\hline Current Ratio & $\mathrm{X}$ & $\checkmark$ & $\checkmark$ & $\checkmark$ & Liquid \\
\hline
\end{tabular}




\begin{tabular}{|l|c|c|c|c|c|} 
Quick Ratio & X & $\checkmark$ & $\checkmark$ & $\checkmark$ & Liquid \\
\hline Cash Ratio & X & $\checkmark$ & $\checkmark$ & $\checkmark$ & Liquid \\
\hline Debt to Assets Ratio & $\checkmark$ & $\checkmark$ & $\checkmark$ & $\checkmark$ & Solvabel \\
\hline Debt to Equity Ratio & $\checkmark$ & $\checkmark$ & $\checkmark$ & $\checkmark$ & Solvabel \\
\hline $\begin{array}{l}\text { Inventory Turn Over } \\
\text { Ratio }\end{array}$ & $\checkmark$ & $\checkmark$ & $\checkmark$ & $\checkmark$ & Efisien \\
\hline Total Assets Turn Over & $\checkmark$ & $\checkmark$ & $\checkmark$ & $\checkmark$ & Efisien \\
\hline $\begin{array}{l}\text { Inventory Turnover } \\
\text { Ratio }\end{array}$ & $\checkmark$ & $\checkmark$ & $\checkmark$ & $\checkmark$ & Efisien \\
\hline Return On Assets & $\checkmark$ & $\checkmark$ & $\checkmark$ & $\checkmark$ & Efisien \\
\hline Return On Equity & $\checkmark$ & $\checkmark$ & $\checkmark$ & $\checkmark$ & Efisien \\
\hline
\end{tabular}

Tabel 3.10 Penilaian Kinerja Keuangan

Sumber: Data sekunder yang diolah

Keterangan :

- $X=$ hasilperhitunganrasioperusahaandibawah rata - rata Industri yang sejenis.

- $\checkmark=$ hasilperhitunganrasioperusahaan di atas rata - rata Industri yang sejenis.

Dari Tabel perhitungan diatas, maka dapat interpretasi kinerja keuangan PT.HM. Sampoerna Tbk. sebagai berikut :

a. Kinerja Keuangan dilihat dari rasio likuiditas :

1) Current Ratio

Secara keseluruhan rata-rata Current Ratio PT. HM. Sampoerna Tbk. dari tahun 2014-2016 sebesar 444,31\%. Dengan demikian Current Ratio PT.HM. Sampoerna Tbk. dikatakan Likuid karena di atas rata-rata angka industri yang sejenis.

2) Quick Ratio

Secara keseluruhan rata-rata Quick Ratio PT. HM. Sampoerna Tbk. dari tahun 2014-2016 sebesar 160,71\%. Dengan demikian Quick Ratio PT. HM. Sampoerna Tbk. dikatakan Likuid karena di atas rata-rata angka industri yang sejenis.

3) Cash Ratio

Secara keseluruhan rata-rata Cash Ratio PT. HM. Sampoerna Tbk. dari tahun 2014-2016 sebesar 39,00 \%. Dengan demikian Cash Ratio PT. HM. Sampoerna Tbk. dikatakan Likuid karena di atas rata-rata angka perusahaan yang sejenis.

b. Kinerja Keuangan dilihat dari rasio solvabilitas :

1) Debt to Assets Ratio

Secara keseluruhan rata-rata Debt to Assets Ratio PT. HM. Sampoerna Tbk. dari tahun 20142016 sebesar 29,27 \%. Dengan demikian Debt to Assets Ratio PT. HM. Sampoerna Tbk. dikatakan Solvabel karena dibawah rata-rata angka industri yang sejenis.

2) Debt to Equity Ratio

Secara keseluruhan rata-rata Debt to Equity Ratio PT. HM. Sampoerna Tbk. dari tahun 20142016 sebesar 47.95 \%. Dengan demikian Debt to Assets Ratio PT HM Sampoerna Tbk. dikatakan Solvabel karena dibawah rata-rata angka industri yang sejenis.

c. Kinerja Keuangan dilihat dari rasio aktivitas :

1) Inventory Turn Over

Secara keseluruhan rata-rata Inventory Turn OverPT. HM. Sampoerna Tbk. dari tahun 20142016 sebesar 43 kali. Dengan demikian Inventory Turn Over PT. HM. Sampoerna Tbk. dikatakan Efisien karena diatas rata-rata angka industri yang sejenis. 
2) Total Assets Turn Over

Secara keseluruhan rata-rata Total Assets Turn OverPT. HM. Sampoerna Tbk. dari tahun 2014-2016 sebesar 2,47 kali. Dengan demikian Total Assets Turn Over PT. HM. Sampoerna Tbk. dikatakan Efisien karena di atas rata-rata angka industri yang sejenis.

d. Kinerja Keuangan dilihat dari rasio Profitabilitas

1) Return On Assets

Secara keseluruhan rata-rata Return On AssetsPT. HM. Sampoerna Tbk. dari tahun 20142016 sebesar 31,05 \%. Dengan demikian Retutn On Assets PT. HM. Sampoerna Tbk. dikatakan Efisien karena di atas rata-rata angka industri yang sejenis.

2) Return On Equity

Secara keseluruhan rata-rata Return On EquityPT. HM. Sampoerna Tbk. dari tahun 20142016 sebesar 48,38 \%. Dengan demikian Retutn On Equity PT. HM. Sampoerna Tbk. dikatakan Efisien karena di atas rata-rata angka industri yang sejenis. 
6. PerhitungandanPembahasan EVA PT. HM. SampoernaTbk. Tahun 2014 - 2016

Tabel 3.11 Perhitungan EVA

\begin{tabular}{|c|c|c|c|}
\hline \multicolumn{4}{|c|}{ Perhitungan EVA } \\
\hline Keterangan & 2014 & 2015 & 2016 \\
\hline NOPAT ( Rp ) & 10.181 .083 & 10.363 .308 & 12.726 .229 \\
\hline Biaya Modal ( Rp ) & 5.514 .928 & 8.931 .151 & 10.894 .401 \\
\hline Biaya Hutang ( rd ) \% & 3,70 & 9,51 & 1,17 \\
\hline Tingkat Modal ( D ) \% & 52,44 & 15,77 & 19,60 \\
\hline Tingkat Ekuitas ( E ) \% & 47,56 & 84,23 & 80,40 \\
\hline Biaya Ekuitas ( re ) \% & 75,43 & 32,37 & 37,34 \\
\hline Tingkat pajak ( Tax ) \% & 25,78 & 25,62 & 24,98 \\
\hline WACC $\%$ & 37,31 & 28,38 & 30,20 \\
\hline Invested Capital ( Rp ) & 14.780 .400 & 31.472 .050 & 36.079 .799 \\
\hline EVA ( Rp ) & 4.661 .155 & 1.431 .717 & 1.867 .828 \\
\hline
\end{tabular}

Sumber: Laporan keuangan PT. HM. Sampoerna Tbk. ( di olah ).

*Dinyatakandalamjutaan Rupiah

Interprestasi :

1. EVA untuk tahun $2014>0$ / positif, maka kinerja keuangan PT. HM. Sampoerna Tbk. pada tahun 2014 memiliki nilai ekonomis (EVA) sebesar Rp4.661.155. Hasil dari EVA ini berhubungan dengan hasil perhitungan rasio profitabilitas sebelumnya. Karena pada perhitungan rasio profitabilitas tersebut yaitu ROE hasilnya paling tinggi disbanding tahun yang lain dengan hasil $75,43 \%$. Yang menunjukan perusahaan menggunakan modalnya dengan baik sehingga menghasilkan laba yang banyak.

2. EVA untuk tahun $2015>0$ / positif, maka kinerja keuangan PT. HM. Sampoerna Tbk. pada tahun 2015 memiliki nilai ekonomis (EVA) sebesar Rp1.431.717. EVA mengalami penurunan ada hubungannya dengan hasil dari perhitungan ROE, karena hasil perhitungan ROE juga mengalami penurunan yaitu menjadi $32,37 \%$. Penurunan tersebut dikarenakan naiknya total modal sendiri namun kurang diimbangi dengan kenaikan EAT, kenaikan total modal ini juga berdampak pada Invested Capital yang naik menjadi Rp31.472.050 yang menyebabkan biaya modal juga naik yang kemudian membuat EVA mengalami penurunan. Walaupun dilihat dari raio - rasio yang lain hasilnya baik namun untuk rasio profitabilitas hasilnya kurang baik, karena mengalami penurunan.

3. EVA untuk tahun $2016>0$ / positif, maka kinerja keuangan PT. HM. Sampoerna Tbk. pada tahun 2016 memiliki nilai ekonomis (EVA) sebesar Rp1.867.828. Kenaikan jumlah EVA pada tahun 2015 dikarenakan naiknnya EAT walaupun total modal sendiri juga mengalami kenaikan. Hal tersebut sama seperti hasil ROE yang juga mengalami kenaikan menjadi $37,34 \%$.

\section{PENUTUP}

1. Kesimpulan

Penilaian kinerjaPT. HM. Sampoerna Tbk. dari tahun 2014 - 2016dengan rasio likuiditas berdasarkan hasil dari tabel3.15, hasilnya Current Ratio, Quick Ratio, dan Cash Ratios ecara keseluruhan rata - rata hasilnya baik jika dibandingkan dengan rata - rata industri yang sejenis. Dengan demikian dapat disimpulkan kinerja PT. HM. Sampoerna Tbk. dari tahun $2014-2016$ dilihat dengan rasio likuiditasnya dalam keadaan yang baik. 
Penilaian kinerjaPT. HM. Sampoerna Tbk. dari tahun 2014 - 2016 dengan rasio solvabilitas berdasarkan hasil dari tabel3.15, hasilnyaDebt to Assets RatiodanDebt to Equity Ratio secara keseluruhan rata-rata hasilnya baik jika dibandingkan dengan rata - rata industri yang sejenis. Dengan demikian dapat disimpulkan kinerja PT. HM. Sampoerna Tbk. dari tahun $2014-2016$ dilihat dengan rasio solvabilitasnya dalam keadaan yang baik.

Penilaian kinerjaPT. HM. Sampoerna Tbk. dari tahun 2014 - 2016dengan rasio aktivitasberdasarkanhasildaritabel3.15, hasilnyaInventory Turn Over RatiodanTotal Assets Turn Oversecarakeseluruhan rata - rata hasilnya baik jika dibandingkan dengan rata - rata industri yang sejenis. Dengan demikian dapat disimpulkan kinerja PT. HM. Sampoerna Tbk. dari tahun $2014-$ 2016 dilihat dengan rasio aktivitasdalam keadaan yang baik.

Penilaian kinerjaPT. HM. Sampoerna Tbk. dari tahun 2014 - 2016dengan rasio profitabilitasberdasarkanhasildaritabel3.15, hasilnyaReturn On AssetsdanReturn On Equitysecarakeseluruhan rata - rata hasilnya baik jika dibandingkan dengan rata - rata industri yang sejenis. Dengan demikian dapat disimpulkan kinerja PT. HM. Sampoerna Tbk. dari tahun 2014 - 2016 dilihat dengan rasio profitabilitas dalam keadaan yang baik.

Berdasarkan hasil perhitungan EVA pada Tabel 3.16 menunjukan kinerja keuangan PT. HM. Sampoerna Tbk.pada tahun 2014 - 2016 dalam keadaan yang baik dengan adanya nilai tambah atau bernilai positif. Yang hasilnya pada tahun 2014 sebesar Rp 4.661 .155 (dalam jutaan) kemudia 2015 sebesar Rp 1.431 .717 (dalam jutaan) dantahun 2016 sebesar Rp 1.867.828 (dalam jutaan).

2. Saran

PT. HM. SampoernaTbk. Hendaknya lebih baik lagi dalam memanfaatkan / mengelola dana atau modal yang sudah ditanamkan, sehingga diharapkan dengan modal yang ada dapat menghasilkan laba yang lebih banyak lagi kedepannya.

\section{E. DAFTAR PUSTAKA}

Abdul, K. 2010. Anlisis Faktor-Faktor Yang Mempengaruhi Kebijakan Dividen Pada Perusahan Credit Agencies Go Publik Di Bursa Efek Indonesia. Jurnal Manajemen Dan Akuntansi 11(1).

Aditya putra dewa, 2015. Analisis Kinerja Keuangan PT Indofood Sukses Makmur tbk di Bursa Efek IndonesiaJurnal Ilmu dan Riset Manajemen Volume 4, Nomor 3, Maret 2015.

Kasmir, 2008, Analisis Laporan Keuangan, PT Raja Geafindopersada, Jakarta.

Harahap, Sofyan Syafri, 2007. Analisis Kritis Atas Laporan Keuangan, PT. Raja Grafindo Persada, Jakarta.

Ria ayu devi, 2014.Perbandingan Antara Economic Value Added (Eva) Dan Return On Assets (Roa) Dalam Menilai Kinerja Perusahaan(studi kasus pada perusahaan rokok go publik yang terdaftar di bursa efek Indonesia periode 2010-2012).

SupriyantodanWidianti Lestari, 2015.AnalisisKinerjaKeuangandenganMenggunakanMetode Economic Value Added Pada PT. Bank Mandiri (Persero), Tbk. JurnalBisnisAdministrasi Volume 04, Nomor 01, 2015, 53-61.

www.idx.co.id(05 Maret 2018, Pukul 19.30 wib).

www.sampoerna.com(05 Maret 2018, Pukul 20.00 wib).

www.gudanggaramtbk.com(28September 2018, Pukul 20.00 wib).

www.bentoelgroup.com( 11Oktober 2018 ,Pukul 22.00).

www.wismilak.com(11 Oktober 2018, Pukul 22.30) 